\title{
Chemical composition, acute and sub-acute toxicity of Satureja khuzestanica essential oil in mice
}

Shirzad Fallahi, Maryam Beyranvand, Hossein Mahmoudvand, Hassan Nayebzadeh, Farnaz Kheirandish, Sareh Jahanbakhsh

\begin{abstract}
To date, herbal medicines are the important source in the development of new drugs to remedy various diseases. However, it is crucial to provide scientific justification of these drugs to determine their side effects in treatments. This study was aimed to evaluate the chemical composition, acute and subacute toxicity of Satureja khuzestanica essential oil (SKEO) in a mice model. Plant materials of S. khuzestanica were collected from the rural regions of Lorestan Province, west of Iran. Gas chromatography/mass spectrometry (GC/MS) analysis was performed to determine the main components of SKEO. To assess the acute toxicity, 0.5, 1, 2 and $4 \mathrm{ml} / \mathrm{kg}$ doses of SKEO were injected intraperitoneally into four groups of six mice. The number of deaths was counted at $24 \mathrm{~h}$ after the treatment. Sub-acute toxicity of the effects of SKEO was evaluated by determine the clinical chemistry and hematological parameters of the treated mice after oral administration of SKEO at the
\end{abstract}

Shirzad Fallahi, Farnaz Kheirandish

Razi Herbal Medicines Research Center, Lorestan University of Medical Science, Khorramabad, Iran

Maryam Beyranvand

Department of Parasitology, Faculty of Veterinary, Borujerd Branch, Islamic Azad, University, Borujerd, Iran

Hossein Mahmoudvand

School of Allied Medical Sciences, Lorestan University of Medical Sciences, Khorramabd, Iran

Hassan Nayebzadeh

Departmentof Pathobiology, Faculty of Veterinary Medicine, Lorestan University, Khorramabad, Iran

Sareh Jahanbakhsh

Research Center for Tropical and Infectious Diseases, Kerman University of Medical Sciences, Kerman, Iran

Sorumlu Yazar:

Sareh Jahanbakhsh

e-posta: sarehjahanbakhsh@gmail.com

Submitted / Gönderilme: 18.01.2017 Revised / Düzeltme: 04.03.2017 Accepted / Kabul: 09.03.2017 doses of $0.2,0.4$ and $0.6 \mathrm{ml} / \mathrm{kg}$, respectively, for 14 consecutive days. Twenty-three compounds were identified in SKEO by GC/MS analysis, in which the main component was carvacrol (64.4\%). The LD50 value of intraperitoneal injection of SKEO was $1.79 \mathrm{ml} / \mathrm{kg}$ and the maximum nonfatal dose was $1.13 \mathrm{ml} /$ $\mathrm{kg}$. No death was observed at the doses of 0.2 and $0.4 \mathrm{ml} / \mathrm{kg}$, while in the group receiving $0.8 \mathrm{ml} / \mathrm{kg}$ of SKEO, only one mouse died $(12.5 \%)$. There was no significant difference between the biochemical and hematological parameters following the oral administrations of SKEO at the used doses of $0.2,0.4$ and $0.8 \mathrm{ml} /$ $\mathrm{kg}$ and the controls $(P>0.05)$. The obtained results in this work showed that SKEO at the tested doses had no significant toxicity on the liver and kidney tissues as well as on the hematological parameters in the mice. Therefore, SKEO could be safe for the mammalian host at the used doses.

Keywords: GC/MS; Acute and sub-acute toxicity; Satureja khuzestanica essential oil; Mice

\section{Introduction}

Since the last centuries, traditional remedy serves people in all countries around the world.

The employ of herbal medicines is generally widespread for the avoidance and treatment of a wide spectrum of diseases such as infectious ones in addition to maintaining the public health (1). Hence, a broad range of medicinal plants is accessible and it is essential to give scientific validation for these drugs for identifying their side effects in treatments $(2,3)$. One of these attractive herbs is Satureja khuzestanica Jamzad (family Lamiaceae). S. khuzestanica (SK) is a remedial plant that is frequently grown in various parts of Iran such as Lorestan Province, West of Iran (4). Different parts of SK such as root, leaves, and branches have been broadly applied as analgesic, anti-diarrhea, and antiseptic in the folk medicine (5). Furthermore, a range of pharmacological activities including antioxidant, antiinflammatory, hepatoprotective and antimicrobial have been related to this plant (5-11). 
Essential oils are originating in aromatic plants and have volatile fractions that are responsible for biological activity, smell, and taste (12). Reviews have reported that the main constituents of S. khuzestanica essential oil (SKEO) in the majority species are phenols, carvacrol, thymol, $p$-cymene, b-caryophyllene, linalool, monoterpenes, sesquiterpenes, alcohols and phenolic acids $(7,12)$. On the other hand, it has been previously proven that the chemical composition of essential oils is directly depended on some factors such as the geographical source and harvesting time $(13,14)$. Previous investigations on laboratory animals have demonstrated that the liver and kidney are the key target organs in the evaluation of toxicity of drugs (15). Damage to the constructional entirety of the liver is evaluated by the elevated serum levels of some important enzymes for example alanine aminotransferase (ALT), aspartate aminotransferase (AST), alkaline phosphatase (ALP) and bilirubin. On the other hand, the creatinine blood test $(\mathrm{Cr})$ and blood urea nitrogen (BUN) are used to evaluate the function of kidneys.

To the best knowledge of the authors, there is no study on the toxicity effects of SKEO. Therefore, the present study was aimed to evaluate the chemical composition, acute and subacute toxicity of SKEO in the mice model by assessing some biochemical and hematological parameters.

\section{Materials and methods}

\section{Plant materials}

Plant materials (aerial parts) of SK were collected from rural regions of Lorestan Province, Western Iran, in May 2015. They were identified by a botanist of the Botany Department of Lorestan University, Khorramabad, Iran. Voucher specimens have been deposited in the herbarium of Research Center for Agriculture Sciences, Khorramabad, Iran (No.3215).

\section{Isolation of the essential oil}

Air-dried plant material was subjected to hydrodistillation for $3 \mathrm{~h}$ using an all-glass Clevenger type apparatus. The obtained essential oil was dried over anhydrous sodium sulfate and stored in darkness at $4^{\circ} \mathrm{C}$ until testing (16).

\section{Gas chromatography/mass spectrometry (GC/MS)}

GC analysis

GC analysis was carried out by Hewlett-Packard 6890 (Hewlett-Packard, Palo Alto, CA) with a HP-5MS column (30 $\mathrm{m} \times 0.25 \mathrm{~mm}$, film thickness $0.25 \mathrm{~mm}$ ). The column temperature was maintained at $55^{\circ} \mathrm{C}$ for $3 \mathrm{~min}$, programmed to $180^{\circ} \mathrm{C}$ in the rate of $5^{\circ} \mathrm{C}$ per min, and kept constant at $220^{\circ} \mathrm{C}$ for $5 \mathrm{~min}$. The injector and interface temperatures were 220 and $290^{\circ} \mathrm{C}$, respectively. The flow rate of helium as a carrier gas was $(1 \mathrm{~mL} /$ min C.F). The percentageswere calculated by the electronic integration of FID peak areas without using response factor correction. Linear retention indices for all the components were determined by the co- injection of the samples with a solution containing homologous series of C8-C22 n-alkanes

\section{GC/MS analysis}

GC/MS analysis was performed using a Thermoquest-Finnigan gas chromatograph equipped with fused silica capillary DB-5 column $(30 \mathrm{~m} \times 0.25 \mathrm{~mm}$, film thickness $0.25 \mathrm{~mm}$ ) coupled with a TRACE mass (CAS, Manchester, UK). Helium was used as the carrier gas with an ionization voltage of $70 \mathrm{eV}$. Ion source and interface temperatures were 220 and $290^{\circ} \mathrm{C}$, respectively. Mass range was from 40 to $400 \mathrm{u}$. Temperature program of the oven was as mentioned above for the GC.

\section{Identifying the essential oil components}

The components of the essential oil were identified by comparing their retention indices and mass spectra with the standards, Wiley 2001 library data of the GC/ MS system, or those reported in the literature data (17).

\section{Animals}

Sixty-four male NMRI mice (3-4 months old, 30-35 g) were obtained from the Animal Breeding Stock Facility of Razi Institute of Iran (Karaj, Iran). Animals were housed in a colony room with a $12: 12 \mathrm{~h}$ light/ dark cycle at $21 \pm 2^{\circ} \mathrm{C}$ and were handled according to standard protocols for the use of laboratory animals.

\section{Acute toxicity}

To determine the acute toxicity, various doses of SKEO (0.5, 1,2 , and $4 \mathrm{ml} / \mathrm{kg}$ ) were administrated as orally into four groups of six mice. The number of deaths was counted at 24 $\mathrm{h}$ after treatment. LD50 values were determined by the Probit test in SPSS software (18).

\section{Sub-acute toxicity}

Sub-acute toxicity of SEKO was evaluated by determination of clinical chemistry and hematological parameters of treated 
mice after orally administration SKEO at the doses of 0.2 , 0.4 , and $0.6 \mathrm{ml} / \mathrm{kg}$, for 14 consecutive days. Forty mice were randomly divided into five groups with 8 mice in each group.

Group 1 was administrated normal saline orally (orogastric gavage).

Groups 2-4 were orally administrated SKEO at the doses of $0.2,0.4$, and $0.6 \mathrm{ml} / \mathrm{kg}$, respectively, for 14 consecutive days.

Group 5 did not receive any drug.

After two weeks, animals were fasted overnight and anesthetized using Ketamine (100 mg/kg) and Xylazine (10 $\mathrm{mg} / \mathrm{kg}$ ) combination. Sodium pentobarbital (70 mg/kg, ip.) was used as euthanasia agent and then the abdomen was opened, and blood samples were obtained from the heart. In order to assess the hematological parametrs, total blood was collected into tubes containing ethylene diamine tetraacetic acid (EDTA) anticoagulant, and hematological parameters, including hemoglobin (HGB), hematocrit (Hct), white blood cell (WBC) counts, red blood cell (RBC) counts, and platelet (PLT) counts were measured. To measure clinical chemistry parameters in serum, blood was collected into tubes containing no anticoagulant, allowed to clot, and serum was separated by centrifugation at $2000 \mathrm{~g}$ for $20 \mathrm{~min}$. The assays of aspartate aminotransferase (AST), alanine aminotransferase (ALT), alkaline phosphatase (ALP), creatinine (Cr), blood urea nitrogen (BUN), and bilirubin (direct and total), were performed using Roche diagnostics kits (Mannheim, Germany) $(19,20)$.

\section{Ethical approval}

This study was carried out in strict accordance with the recommendations in the Guide for the Care and Use of Laboratory Animals of the National Institutes of Health. The protocol was approved by the Committee on the Ethics of Animal Experiments of the Lorestan University of Medical Science (Permit Number: 91/27, 2013).

\section{Statistical analysis}

Obtained results are expressed as the mean \pm SEM. Data analysis was carried out by using SPSS statistical package version 17.0 (SPSS Inc., Chicago, IL, USA). One-way ANOVA with Tukey's post-hoc test was used to assess differences between experimental groups. In addition, $p<0.05$ was considered statistically significant.

\section{Results}

\section{GC/MS analysis of SKEO}

The major components of SKEO were found by GC/MS analysis. Table 1 indicates the obtained findings by GC/MS

Table 1. Essential oil composition of S. khuzestanica identified by GC-MS

\begin{tabular}{|c|c|c|c|}
\hline No & Components & RT & \% Composition \\
\hline 1. & $\beta$-Myrcene & 9.47 & 0.1 \\
\hline 2. & 1-Phellandrene & 9.89 & 0.2 \\
\hline 3. & $a$-Terpinene & 10.31 & 0.2 \\
\hline 4. & $\rho$-Cymene & 10.41 & 0.8 \\
\hline 5. & Limonene & 10.73 & 0.2 \\
\hline 6. & $\gamma$-Terpinene & 11.69 & 0.3 \\
\hline 7. & $\alpha$ - Terpineolene & 12.67 & 0.2 \\
\hline 8. & Linalool & 12.88 & 0.5 \\
\hline 9. & Borneol & 14.85 & 0.5 \\
\hline 10 . & Terpinene-4-ol & 15.27 & 0.9 \\
\hline 11. & $\alpha$-Terpineolene & 15.86 & 0.3 \\
\hline 12. & Thymol & 18.53 & 7.5 \\
\hline 13. & Carvacrol & 18.96 & 64.4 \\
\hline 14. & Carvone & 19.16 & 20.2 \\
\hline 15. & 3-Methyl-4-isopropylphenol & 19.36 & 0.2 \\
\hline 16. & Eugenol acetate & 20.16 & 0.2 \\
\hline 17. & $\beta$-Caryophyllene & 22.43 & 0.12 \\
\hline 18. & Geranyl aceton & 22.78 & 0.1 \\
\hline 19. & $\beta$-Bisabolene & 24.57 & 1.2 \\
\hline 20. & a-Bisabolene & 25.23 & 1.2 \\
\hline 21. & Cis-Alpha-Bisabolene & 25.32 & 0.2 \\
\hline 22. & Isoterpinolene & 26.00 & 0.13 \\
\hline 23. & 3-Ethyl-2,5-dimethylpyrazine & 26.42 & 0.07 \\
\hline \multicolumn{3}{|c|}{ Total } & 99.74 \\
\hline
\end{tabular}

a Retention indices on non-polar DB-5 ms column in reference to $n$-alkanes 
analysis of SKEO. Twenty-three compounds were identified, which indicated $99.74 \%$ of the total oil. The main components were carvacrol (64.4\%), carvone (20.2\%) and thymol (7.5\%), respectively.

\section{Acute toxicity}

Acute toxicity effects of SKEO were evaluated on the male NMRI mice. The LD50 value of oral administration of SKEO was $1.79 \mathrm{ml} / \mathrm{kg}$ and the maximum nonfatal dose was $1.13 \mathrm{ml} /$ $\mathrm{kg}$.

\section{Clinical chemistry and hematological parameters}

In accordance with the acquired results of LD50, the doses of $0.2,0.4$ and $0.6 \mathrm{ml} / \mathrm{kg}$ were chosen to evaluating the subacute toxicity of SKEO. There is no death at the doses of 0.2 and $0.4 \mathrm{ml} / \mathrm{kg}$, while in the group receiving $0.6 \mathrm{ml} / \mathrm{kg}$ of SKEO, one mouse died (12.5\%). As shown in Tables 2 and 3, no significant difference $(P>0.05)$ was observed between the biochemical and hematological parameters subsequently the oral administrations of SKEO at the used doses of 0.2, 0.4 and $0.6 \mathrm{ml} / \mathrm{kg}$ and the control.

\section{Discussion}

A rising number of people are using plants and their derivates for protective and curative purposes around the world. Approximately, twenty percent of all the plants are applied for therapeutic use, whereas nearly $10 \%$ of them are applied for commercial goals. Moreover, natural products are measured as a key resource in the pharmaceutical industry and probing for new possible sources of bioactive molecules $(1,2)$. This study was designed to evaluate the acute and subacute toxicity of SKEO in the mice model by assessing some chemical and hematological parameters. Liver function tests which are indicator of enzymes function are a collection of blood experiments that recognize inflammation and injury including hepatitis and cirrhosis to the liver. BUN examination is mainly applied in company with the creatinine test to assess the kidney function in a broad spectrum of conditions, to make possible diagnosing kidney diseases and to monitor people with acute or chronic renal dysfunction or failure (21). The obtained findings demonstrated that the LD50 value of intraperitoneal injection of the SKEO was 1.79 $\mathrm{ml} / \mathrm{kg}$ and the maximum nonfatal dose was $1.13 \mathrm{ml} / \mathrm{kg}$ body weight. We found no significant difference $(P>0.05)$ between the biochemical parameters of ALT, AST, ALP, and bilirubin for assessment the liver function as well as $\mathrm{Cr}$ and BUN for renal function, following the oral administrations of SKEO at the used doses of $0.2,0.4$ and $0.6 \mathrm{ml} / \mathrm{kg}$, and the control.

In line with our results, Abdollahi et al. (2003) demonstrated that the oral administration of SKEO to the rats induced the noticeable antioxidant, antidiabetic, antihyperlipidemic and duplicate stimulatory effects without the incidence of any toxic or unfavorable effects (22). Assaei et al. (2014) demonstrated that the administration of SK had a hepatoprotective effect in hyperthyroid rats during normalizing the enzymatic activities of serum AST and ALT and was more efficient when being applied with vitamin E (23). Previously, it has been proven that the main monoterpenic phenol of SKEO such as carvacrol has antioxidant, anti- inflammatory and hepatoprotective properties (24). Recently, Palabiyik et al. (2016) reported that thymol and carvacrol sheltered against acetaminophen-induced toxicity in HepG2 cells by increasing antioxidant action and diminishing pro inflammatory cytokines, for example tumor necrosis factor a and interleukin $1 \mathrm{~b}$ (25). A previous study conducted by Ahmadvand et al. (2015) demonstrated that carvacrol enhanced the loss of leukocyte infiltration (9.42\%) and tubular necrosis and indicated helpful properties on the kidney function examination in gentamicin- induced nephrotoxicity in rats (26). Samarghandian et al. (2016) also

Table 2. Clinical chemistry parameters in mice sera (Mean \pm SD).

\begin{tabular}{cccc}
\hline \multirow{2}{*}{ Parameters } & \multicolumn{3}{c}{$\begin{array}{c}\text { S. khuzistanica essential } \\
(\mathrm{mL} / \mathrm{kg})\end{array}$} \\
\cline { 2 - 4 } & 0.2 & 0.3 & \multirow{2}{*}{ Contro } \\
\hline AST (U/L) & $159.6 \pm 10.5$ & $162.3 \pm 19.3$ & $124 \pm 11.5$ \\
ALT (U/L) & $85.2 \pm 6.6$ & $102 \pm 9.6$ & $80 \pm 12.3$ \\
ALP (U/L) & $186.2 \pm 23.4$ & $212.1 \pm 23.5$ & $280 \pm 16.5$ \\
Cr (mg/dL) & $0.45 \pm 0.07$ & $0.42 \pm 0.08$ & $0.4 \pm 0.05$ \\
BUN (mg/dL) & $64.3 \pm 6.1$ & $60.1 \pm 1.51$ & $61.4 \pm 2.15$ \\
TB (mg/dL) & $0.1 \pm 0.2$ & $0.11 \pm 0.15$ & $0.89 \pm 0.1$ \\
DB (mg/dL) & $0.04 \pm 0.01$ & $0.06 \pm 0.02$ & $0.1 \pm 0.015$ \\
\hline
\end{tabular}

AST, aspartate aminotransferase; ALT, alanine aminotransferase; ALP, alkaline phosphatase; Cr, creatinine; BUN, Blood urea nitrogen; TB, Total bilirubin; DB, Direct bilirubin. 
Table 3. Hematology parameters in whole blood (Mean \pm SD).

\begin{tabular}{|c|c|c|c|}
\hline \multirow[t]{2}{*}{ Parameters } & \multicolumn{2}{|c|}{$\begin{array}{l}\text { S. khuzistanica essential } \\
(\mathrm{mL} / \mathrm{kg})\end{array}$} & \multirow[t]{2}{*}{ Control } \\
\hline & 0.2 & 0.3 & \\
\hline $\mathrm{RBC}\left(\times 10^{6} / \mu \mathrm{L}\right)$ & $5.82 \pm 0.24$ & $5.7 \pm 0.29$ & $5.4 \pm 0.23$ \\
\hline HGB (g/dL) & $9.4 \pm 1.23$ & $9.7 \pm 1.07$ & $11.3 \pm 0.71$ \\
\hline Hct (\%) & $35.3 \pm 2.5$ & $38.2 \pm 1.25$ & $41.3 \pm 1.18$ \\
\hline $\mathrm{WBC}\left(\times 10^{3} / \mu \mathrm{L}\right)$ & $2.7 \pm 0.22$ & $2.9 \pm 0.61$ & $2.5 \pm 0.2$ \\
\hline $\operatorname{PLT}\left(\times 10^{3} / \mu \mathrm{L}\right)$ & $291.4 \pm 33.1$ & $275.3 \pm 25.56$ & $319.3 \pm 28.2$ \\
\hline
\end{tabular}

RBC, red blood cell; HGB, hemoglobin; Hct, hematocrit; WBC, white blood cell; PLT, platele

reported that carvacrol be able to hold back repeated stressinduced oxidative injure in the brain, liver, and kidneys so that it might be measured as a new pharmacological drug to decrease chronic stress-induced oxidative damage (27). Thus, it should be suggested that SKEO may protect the constructional entirety of the liver and kidney by carvacrol as the main component of essential oil.

Here, we found that SKEO had no significant change in hematological parameters such as HGB, Hct, WBC, RBC, and PLT counts. Hashemipour et al. (2013), demonstrated that the hematological parameters were not affected by means of the combination of thymol and carvacrol, while this mixture amplified antioxidant enzyme activities, retarded lipid oxidation and enhanced immune response in broiler chickens (24).

The GC/MS analysis of SKEO demonstrated that the main components were carvacrol (64.4\%), carvone (20.2\%) and thymol (7.5\%), respectively. Consistent with our study, Kheirandish et al. (28) and Farsam et al. (29) have demonstrated that the main component of SKEO is

Satureja khuzestanica uçucu yağının kimyasal bileşimi, farelerde akut ve sub-akut toksisitesi

ÖZ

Bitkilerin çeşitli hastalıkların tedavisi için ilaç geliştirme amacıyla kullanılan önemli kaynaklar olduğu bilinmektedir ancak bitkisel ilaçların tedavi amacıyla kullanılabilmesi için yan etki profillerinin belirlenmesi gereklidir. Bu çalışmada, Satureja khuzestanica uçucu yağının (SKEO) kimyasal bileșiminin tespiti ve bir fare modelinde akut ve sub-akut toksisitesinin gösterilmesi amaçlanmıştır. Satureja khuzestanica örnekleri İran'ın batısındaki Lorestan bölgesinin kırsal alanlarından toplanmıştır. SKEO'nun kimyasal bileşimi gaz kromatografisi/ kütle spektrometrisi (GC/MS) yöntemiyle belirlenmiştir. Akut toksisitesinin belirlenmesi amaciyla SKEO, 0.5, 1, 2 and $4 \mathrm{ml} / \mathrm{kg}$ dozlarda 6şar fareden oluşan 4 gruba intraperitoneal enjeksiyonla uygulanmıştır. Uygulamadan 24 saat sonra ölen fareler sayılmıştır. SKEO'nun sub-akut toksik etkilerinin belirlenmesi için 14 gün boyunca oral yoldan $0.2,0.4$ and 0.8 $\mathrm{ml} / \mathrm{kg}$ dozlarda SKEO uygulanan farelerin biyokimyasal ve hemotolojik parametreleri incelenmiştir. carvacrol. However, it should be mentioned that the chemical composition of essential oils is dependent on species, type of weather, gathering time and growth phase, indicating the change of the studied biological activities $(30,31)$.

\section{Conclusion}

The obtained results in this work showed that SKEO at the tested doses had no significant toxicity on the liver and kidney tissues as well as on hematological parameters in NMRI mice for 14 days; however further investigations are required to evaluate other toxicity aspects of the SKEO such as genotoxicity, chronic toxicity. Therefore, SKEO could be safe for the mammalian host at the used doses.

\section{Declaration of Interest}

The authors declare that there is no conflict of interest in this study.

GC-MS yöntemiyle yapılan çalışmada SKEO içeriğinde bulunan 23 bileşik tespit edilmiş ve bu bileşikler içerisinde en yüksek miktarda bulunan türevin \%64.4 oranıla karvakrol olduğu görülmüştür. İntraperitoneal enjeksiyon yoluyla uygulanan SKEO’nun LD50 değeri $1.79 \mathrm{ml} / \mathrm{kg}$, maksimum öldürücü olmayan dozu ise $1.13 \mathrm{ml} / \mathrm{kg}$ olarak bildirilmiştir. SKEO'nun; 0.2 and $0.4 \mathrm{ml} / \mathrm{kg}$ dozlarda uygulandığı gruplarda ölüm tespit edilmezken bileşiğe $0.8 \mathrm{ml} / \mathrm{kg}$ dozda maruz falan farelerden sadece biri ölmüştür (\%12.5). Oral yoldan 0.2, 0.4 and $0.8 \mathrm{ml} / \mathrm{kg}$ dozlarda SKEO uygulanan farelerin biyokimyasal ve hemotolojik parametreleri kontrol grubuna ait değerlerle karşılaştırıldığında anlamlı bir farklılık tespit edilmemiştir $(P>0.05)$. Bu çalışma sonucunda elde edilen veriler; SKEO'nun, farelerin karaciğer, böbrek dokuları ve kan parametreleri üzerinde belirgin bir toksistesi olmadığını göstermiştir. Bu nedenle SKEO'nun belirtilen dozlarda diğer memeliler için de güvenli olduğu düşünülmektedir.

Anahtar kelimeler: GC/MS; Akut ve sub-akut toksiste; Satureja khuzestanica uçucu yağı, fare 


\section{References}

1. Cosa P, Vlietinck AJ, Berghe DV, Mae L. Anti-infective potential of natural products: How to develop a stronger in vitro 'proof-of-concept'. J Ethnopharmacol 2006; 106: 290-302.

2. Cowan MM. Plant products as antimicrobial agents. Clin Microb Rev 1999; 12:564-82.

3. Mahmoudvand H, Saedi Dezaki E, Ezatpour B, Sharifi I, Kheirandish F, Rashidipour M. In vitro and in vivo antileishmanial activities of Pistacia vera essential oil. Planta Medica 2016; 82: 279-84.

4. Hadian J, Mirjalili MH, Kanani MR, Salehnia A, Ganjipoor P. Phytochemical and morphological characterization of Satureja khuzistanica Jamzad populations from Iran. Chem Biodivers 2011;8:902-15.

5. Jafari F, Ghavidel F, Zarshenas MM. A critical overview on the pharmacological and clinical aspects of popular Satureja species. J Acupunct Meridian Stud. 2016; 9:118-27.

6. Hajhashemi V, Sadraei H, Ghannadi AR, Mohseni M. Antispasmodic and anti-diarrhoeal effect of Satureja hortensis L. essential oil. J Ethnopharmacol 2000;71:187-92.

7. Safarnavadeh T, Rastegarpanah M. Anti-oxidants and infertility treatment, the role of Satureja khuzestanica: A minisystematic review. Iranian J Reprod Med 2011;9:61- 70.

8. Sanchez de Rojas V, Somoza B, Ortega T, Villar AM, Tejerina T. Vasodilatory effect in rat aorta of eriodictyol obtained from Satureja obovata. Planta Med 1999;65:234-8.

9. Ghazanfari G, Minaie B, Yasa N, Nakhai LA, Mohammadirad A, Nikfar S, Dehghan G, Boushehri VS, Jamshidi H, Khorasani R, Salehnia A, Abdollahi M. Biochemical and histopathological evidences for beneficial effects of Satureja khuzestanica jamzad essential oil on the mouse model of inflammatory bowel diseases. Toxicol Mech Methods 2006;16:365-72.

10. Sadeghi-Nejad B, Shiravi F, Ghanbari S, Alinejadi M, Zarrin M. Antifungal activity of Satureja khuzistanica (Jamzad) leaves extracts. Jundishapur J Microbiol 2010;3:36-40.

11. Amanlou M, Fazeli MR, Arvin A. Antimicrobial activity of crude methanolic extract of Satureja khuzistanica. Fitoterapia 2004;75:768-70.

12. Farsam H, Amanlou M, Radpour MR, Salehinia AN, Shafiee A. Composition of the essential oils of wild and cultivated Satureja khuzistanica Jamzad from Iran. Flavour Frag J 2004;19:308-10.

13. Saedi Dezaki E, Mahmoudvand H, Sharififar F, Fallahi S, Monzote L, Ezatkhah F. Chemical composition along with anti-leishmanial and cytotoxic activity of Zataria multiflora. Pharm Biol 2015; 8: 1-7.

14. Yesil Celiktas O, Hames Kocabas EE, Bedir E, Vardar Sükan F, Özek T, Baser HCK. Antimicrobial activities of methanol extracts and essential oils of Rosmarinus officinalis, depending on location and seasonal variations. Food Chem 2007;100:5539.

15. Diskin CJ, Tomasso CL, Alper JC, Glaser ML, Fliegel SE. Longterm selenium exposure. Arch Intern Med 1979; 139: 824-6.

16. Tavakoli Kareshk A, Keyhani A, Mahmoudvand H, Tavakoli Oliaei R, Asadi A, Andishmand M, Azzizian H, Babaei Z, ZiaAli N. Efficacy of the Bunium persicum (Boiss) essential oil against acute toxoplasmosis in mice model. Iran J Parasitol 2015;10:625-31.

17. Adams RP. Identification of Essential Oil Components by Gas Chromatography/Mass Spectroscopy. Carol Stream, IL: Allured Publishing Corporation. 2007.

18. Mahmoudvand H, Kheirandish F, Ghasemi Kia M, TavakoliKareshk A, Yarahmadi M. Chemical composition, protoscolicidal effects and acute toxicity of Pistacia atlantica Desf. fruit extract. Nat Prod Res 2016;30: 1208-11.

19. Mahmoudvand H, Kheirandish F, Saedi Dezaki E, Shamsaddini S, Fasihi Harandi M, Chemical composition, efficacy and safety of Pistaciavera (var. Fandoghi) to inactivate protoscoleces during hydatid cyst surgery. Biomed Pharmacother 2016; 82: 393-8.

20. Mahmoudvand H, Fallahi Sh, Mahmoudvand H, Shakibaie M, Harandi MF, Dezaki ES. Efficacy of Myrtuscommunis L. to inactivate the hydatid cyst protoscoleces. J Invest Surg 2015; 18: 1-7.

21. Mahmoudvand H, Tavakoli Oliaei R, Mirbadie SR, Kheirandish F, Tavakoli Kareshk A, Ezatpour B, Mahmoudvand H. Efficacy and safety of Bunium Persicum (Boiss) to inactivate protoscoleces during hydatid cyst operations. Surg Infect (Larchmt) 2016;17:713-9.

22. Abdollahi M, Salehnia A, Mortazavi SH, Ebrahimi M, Shafiee A, Fouladian F, Keshavarz K, Sorouri S, Khorasani R, Kazemi A. Antioxidant, antidiabetic, antihyperlipidemic,reproduction stimulatory properties and safety of essential oil of Satureja Khuzestanica in rat in vivo: a oxicopharmacological study. Med Sci Monit 2003;9:BR331-5

23. 23.Assaei R, Mostafavi-Pour Z, Pajouhi N, Ranjbar Omrani GH, Sepehrimanesh M, Zal F. Effects of essential oil of Satureja khuzestanica on the oxidative stress in experimental hyperthyroid male rat. Vet Res Forum 2015 Summer; 6: 233-8.

24. 24.Hashemipour H, Kermanshahi H, Golian A, Veldkamp T. Effect of thymol and carvacrol feed supplementation on performance, antioxidant enzyme activities, fatty acid composition, digestive enzyme activities, and immune response in broiler chickens. Poult Sci 2013;92:2059-69.

25. Palabiyik SS, Karakus E, Halici Z, Cadirci E, Bayir Y, Ayaz G, Cinar I. The protective effects of carvacrol and thymol against paracetamol-induced toxicity on human hepatocellular carcinoma cell lines (HepG2). Hum Exp Toxicol 2016 [Epub ahead of print].

26. Ahmadvand H, Tavafi M, Assadollahi V, Jafaripour L, Hadipour-Moradi F, Mohammadrezaei-Khoramabadi R, Khosravi P, Salehi H, Cheraghi A. Protective effect of carvacrol on renal functional and histopathological changes in gentamicin-induced-nephrotoxicity in rats. Zahedan J Res Med Sci 2013; 8: 23-8.

27. Samarghandian S, Farkhondeh T, Samini F, Borji A. Protective effects of carvacrol against oxidative stress induced by chronic stress in rat's brain, liver, and kidney. Biochem Res Int 2016; 2016: 2645237.

28. Kheirandish F, Delfan B, Farhadi S, Ezatpour B, Khamesipour A , Kazemi B, Ebrahimzade F, Rashidipour M. The effect of Satureja khuzestanica essential oil on the lesions induced by Leishmania major in BALB/c mice. African J Pharm Pharmacol 2011; 5: 648-53. 
29. Farsam H, Amanlou M, Radpour MR, Salehinia AN, Shafiee A. Composition of the essential oils of wild and cultivated Satureja khuzistanica Jamzad from Iran. Flavour Frag J 2004;19:308-10.

30. Ezatpour B, Saedi Dezaki E, Mahmoudvand H, Azadpour $\mathrm{M}$, Ezzatkhah F. In vitro and in vivo antileishmanial effects of
Pistacia khinjuk against Leishmania tropica and Leishmania major. Evid Based Complement Alternat Med 2015; 149707.

31. Mahmoudvand H, Tavakoli R, Sharififar F, Minaie $\mathrm{K}$, Ezatpour B, Jahanbakhsh S, Sharifi I. Leishmanicidal and cytotoxic activities of Nigella sativa and its active principle, thymoquinone. Pharm Biol 2015; 53:1052-7. 